\title{
THE MISSING SOFT LINK? EVIDENCE FOR MARGINAL FAULT INTERACTION AT THE SOUTHERN MARGIN OF GERANEIA MOUNTAINS, CENTRAL GREECE
}

\author{
Kranis H. ${ }^{1}$ \\ ${ }^{1}$ National and Kapodistrian University of Athens, Faculty of Geology and Geoenvironment, 15784 \\ Zographou, Athens, hkranis@geol.uoa.gr
}

\begin{abstract}
We examine the structure of the southern faulted margin of Geraneia Mountains, controlled by two marginal faults, namely the Loutraki and Kakia Skala Faults, which have been active in the Quaternary; however, Holocene activity on these structures has not been verified. Structural observations at the probable overlap zone between these two faults, suggest that they became soft-linked, or linkage ended at its early stage, before activity migrated basinwards, with consequent footwall backtilt. The affinity of the kinematics in the accommodation zone with the present-day extensional stress field might hint at possible Late Quaternary activity on these two major faults. Keywords: Gulf of Corinth, oblique-slip faulting, accommodation zone, flower structure.
\end{abstract}

\section{Пврі́ $\eta \psi \eta$}

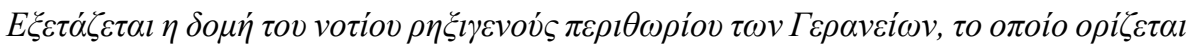

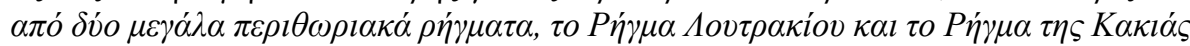

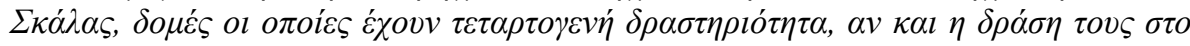

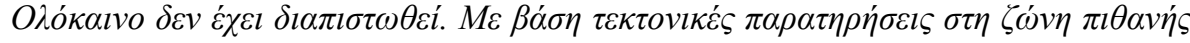

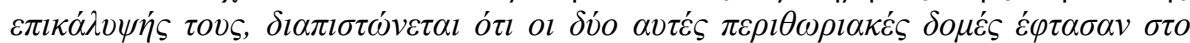

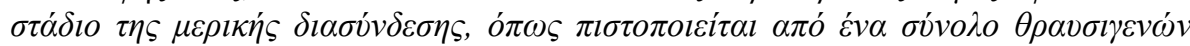

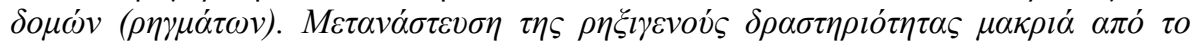

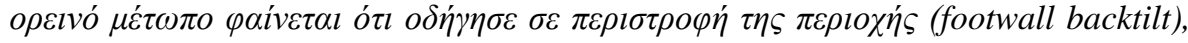

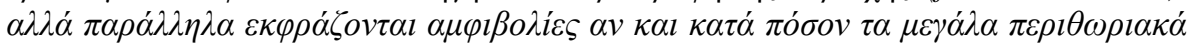

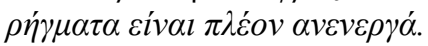

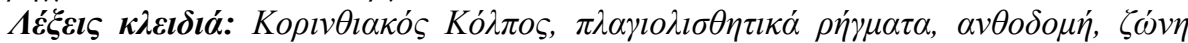
$\pi \rho о \sigma \alpha \rho \mu о \gamma \dot{\eta} \varsigma$.

\section{Introduction}

The broader Corinth Isthmus area lies at the eastern extremity of the Gulf of Corinth, being the landstrip that separates it from the Saronic Gulf in the east (Fig. 1). The area corresponds to a major E-W graben, hosting several hundreds of $m$ of synrift sediments, bounded between the south-dipping faults that border Geraneia Mountains in the north and the north-dipping Kenchreai fault system (KFS) in the south. Currently the area is undergoing a generalized uplift, in the order of 0.2-0.3 $\mathrm{mm} / \mathrm{yr}$ for reasons still poorly understood (see Leeder et al., 2008 for discussion).

The northern margin of the area is marked by two range-bounding faults, namely the Loutraki Fault $(\mathrm{LF})$ in the west and the Kakia Skala Fault (KSF) in the east. Both faults are considered to be inactive, 
(e.g. Mack et al., 2009), or at least without clear evidence for Holocene activity. The mean strike of the $\mathrm{LF}$ is $\mathrm{N} 80^{\circ} \mathrm{E}$, but the $\mathrm{KSF}$ has been shown to comprise linked segments of varying geometry (Mack et al., 2009). The kinematics of these faults deviates markedly from being pure dip-slip. Measurements taken from striated slickensides on both faults show that they both have a significant component of sinistral slip, with WSW-oriented displacement vectors (Fig. 1), remarkably persistent throughout the extent of these faults.

The purpose of this study was the examination of the probable interaction between and the identification of structures that accommodate deformation between these two oblique-slip structures, with same sense of displacement. The study was based on field mapping, collection of structural data and outcrop photo interpretation.

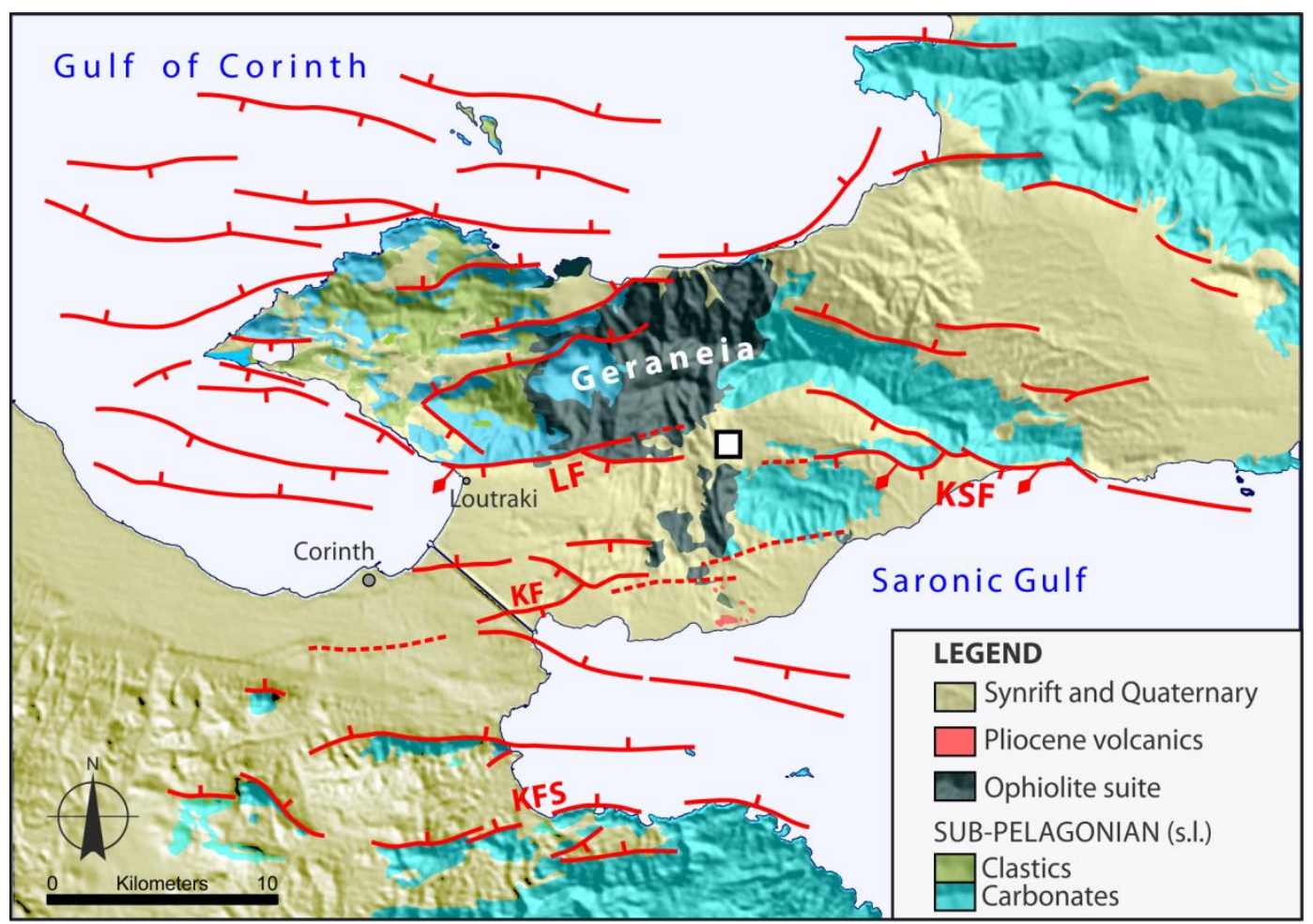

Figure 1 - Summary shaded relief map of the Corinth Isthmus area. Structural data from Freyberg (1973), Gaitanakis et al. (1985), Collier and Dart (1991), Mack et al. (2009), Charalampakis et al. (2014), Nixon et al. (subm.) and own mapping. LF: Loutraki Fault; KSF: Kakia Skala F.; KF: Kalamaki F.; KFS: Kenchreai Fault System. Diamond-ended lines on KSF and LF denote mean displacement vector from three measurement stations. Box indicates location of study area, shown in Fig. 2.

\section{Geological Setting}

The study area is located between the eastern extremity of the Gulf of Corinth and the western termination of the Saronic Gulf, forming a semi-mountainous and low-lying area, at the hangingwalls of the LF and the KSF (Fig 1).

The synrift formations comprise a stratigraphic sequence of probable Pliocene age, referred to as the Asprohomata-Kalamonas formation, by Gaitanakis et al., 1985), equivalent to the Charalampos marl formation (CMF) of Collier and Dart's (1991). According to the latter, the formation consists of calcareous mudstones and siltstones, with channelized sandstone bodies in its northern part and a 
general coarsening trend towards the north-east, indicating a paleoflow towards the south. In terms of depositional environment, CFM is interpreted to represent a range of lacustrine and alluvial environments (Collier and Dart, 1991). Overlying CFM is a ca 150-m thick package of angular to rounded conglomerates, intercalated with coarse sands and including silty or clayey horizons, interpreted as a (?)Late Pleistocene fan sourced mainly from the uplifted Geraneia and mostly consisting of ophiolitic clasts.

Andesite occurrences of probable age of 3.4-4.5 Ma (Collier and Dart, 1991), related to the Sousaki volcanic centre are also mapped, as isolated relic occurrences, usually overlying the Lower Pliocene formations (Collier and Dart, 1991).

The pre-rift ('alpine') formations belong to the Pelagonian zone and are mainly represented by Mesozoic neretic limestones and an ophiolite thrust sheet, exposed at Geraneia Mountains. The latter, which is highly erodible, is the main source of material for the (?) L. Pleistocene fluvials that dominate the study area.

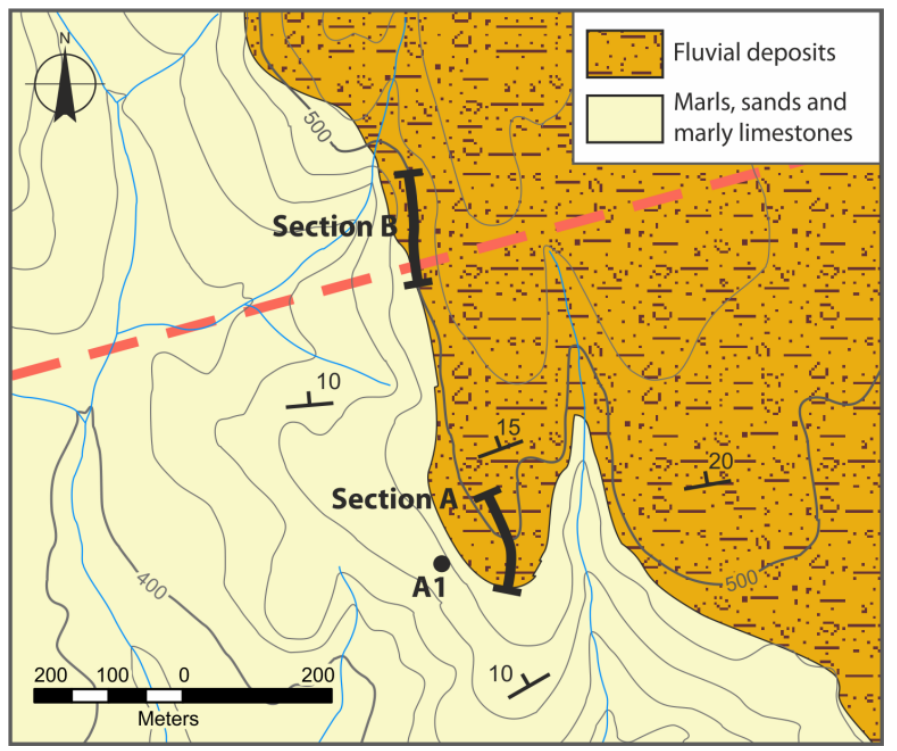

Figure 2 - Geological map of the study locations at Dárthiza, modified from Gaitanakis et al., 1985. Thick dashed line is the trace of inferred fault in the same map.

\section{Structural observations at Dárthiza}

Two key locations for the determination of the deformation pattern are found at Dárthiza, ca. $12 \mathrm{~km}$ west of Loutraki (Figs 1, 2). Fault suites are exposed mainly in two sites, along a N-S artificial roadcut, about $150 \mathrm{~m}$ long (Section $\mathrm{A}$ ), and on a cliff exposure, also N-S, ca $150 \mathrm{~m}$ long and 5-30 $\mathrm{m}$ high (Section B) (Fig 2.). The former location is within easy reach and readily examinable, while the latter is largely inaccessible and most readings were made through panoramas, with a few of them obtained from the basal part of the cliff exposure, where these were reachable. The fact that these two sections are aligned N-S, and given that the average strike of the structures observed is roughly E-W, allows for a geometrically correct reconstruction of the deformation structures in the study area. Another exposure of limited extent (ca $20 \mathrm{~m}$ ), located $120 \mathrm{~m} \mathrm{WSW}$ of the southern termination of Section A, provides additional constraints on the geometry of the studied faults (Site A1 in Fig. 2).

All faults that crop out in the area are post-depositional, meaning that no syn-sedimentary features associated with faulting activity were observed. Their strikes range from ENE-WSW to ESE-WNW and they present practically all kinematic modes, from dip-slip (either normal or reverse) to oblique- 
and strike slip. Displacements on these faults are usually small, from few to several meters. In the following, sections, as well as in Fig 3, only faults with vertical throws of more than several decimeters are taken into account. However, numerous minor faults, with vertical throws from a few to several centimeters are also present, but their identification is usually hindered by the poor internal stratification of the fluvials and the weathering of the outcrops.

Estimation of apparent vertical displacement was made on the basis of extensive, planar soil beds, which offer sufficient extent and geometrical consistency. In some cases, throws were estimated by 'internal' sedimentary features within the fluvial deposits, such as sandy intercalations, which, due to their increased erodibility, are easier to pick up on the cross section. In all cases, the lateral continuity, thickness consistency and planar geometry of the sedimentary bodies established before any measurements or calculations were made.

\subsection{Section A}

A suite of faults cutting through both the fluvial deposits and the top of the underlying CMF was exposed, after widening of a dirt track that leads from Loutraki to the foot of Mt Geraneia. The roadcut offers a $155-\mathrm{m}$ long and 4-15-m high N-S section practically parallel to the local fault grain (Fig. 2). Five extensive, medium-developed palaeosol horizons, 20-40 m thick, were identified within the ca $45 \mathrm{~m}$ thickness of the exposed fluvial sediments (Fig 3). The fact that these palaeosols are planar and persist throughout the section allowed for the estimation of the kinematics of the faults that cut through the succession, as the crude stratification and poor internal organization and sedimentarly structure of the fluvials do not favour unambiguous correlations across the observed faults.

Figure 3 is an overview of the exposed roadcut, with only the main faults marked, for reasons of clarity. Overall, out of the 22 exposed faults, 17 of them present apparent vertical displacements of more than a few decimeters. Table 1 summarises the characteristics of the faults with apparent vertical displacement more than $0.2 \mathrm{~m}$; selected fault outcrops are presented in Fig. $3 \mathrm{~B}$, C, and D.

\subsection{Analysis of fault-slip data}

Out of a dataset of 53 fault measurements, 23 of them included kinematic indicators (striae) of acceptable quality. The remainder, which did not include kinematic indicators, or they were of poor quality, were not included in our calculations.

The analysis of data followed the guidelines suggested by Sperner and Zweigel (2010) and the homogeneity of the fault dataset was first ensured before embarking into any further calculations. We chose two methods for fault-slip analysis, namely Angelier and Cocquel's (1979) right-dihedra method (RDM) and Numerical Dynamic Analysis (NDA), based on Spang's (1972) original method. The choice of methods was guide by objective factors, especially the location of outcrops (i.e. along a N-S transect) which hinders the recognition of faults highly oblique or parallel to the exposed roadcut. In our case, according to the conclusions of Sperner and Zweigel (2010), NDA produces reasonable results, albeit with low confidence in the computed stress ratio $\mathrm{R}$. All calculations were made through the in TectonicsFP v.1.7.8 software package (Reiter and Acs, 2015).

The RDM resulted in major and minor stress axes gently plunging towards the SSE and N, respectively, with the intermediate axis close to horizontal ( $\sigma 1: 157 / 32, \sigma 2: 260 / 14, \sigma 3: 008 / 54)$. NDA came up with similar results, with the major and minor axes being closer to vertical and horizontal, respectively ( $\sigma 1: 150 / 60, \sigma 2: 260 / 11, \sigma 3: 356 / 27)$. For the reasons stated above, we believe that the results of NDA are more reasonable, given the limitations of our dataset. 
Table 1 - Summary of the characteristics of the main faults identified in Section A and location A1 (See Fig 2 for locations).

\begin{tabular}{|c|c|c|c|c|}
\hline Fault & Geometry & $\begin{array}{l}\text { Kinematics } \\
\text { (rake) }\end{array}$ & $\begin{array}{l}\text { Displacement } \\
* * \text {-sense }\end{array}$ & Comments \\
\hline $\mathrm{F} 1$ & $171 / 60$ & $90 \mathrm{E}$ & $\begin{array}{l}0.55 \mathrm{~m}, \\
\text { reverse }\end{array}$ & $\begin{array}{l}\text { Exposed for ca } 4 \mathrm{~m} \text { in cross-section; } \\
\text { steeply dipping structure, flattening } \\
\text { slightly updip }\end{array}$ \\
\hline $\mathrm{F} 2$ & $175 / 65$ & $90 \mathrm{E}$ & $1.8 \mathrm{~m}$, reverse & $\begin{array}{l}\text { It has caused tilting of its hanging-wall } \\
\text { by ca } 5^{\circ} \text {; it flattens updip, and a fault } \\
\text { duplex is observed, bounded by a more } \\
\text { gently dipping sole fault and a steeper } \\
\text { roof fault. }\end{array}$ \\
\hline F5 & $172 / 66$ & $70 \mathrm{E}$ & $\begin{array}{l}1.9 \mathrm{~m} \text {, } \\
\text { oblique- } \\
\text { reverse }\end{array}$ & $\begin{array}{l}\text { It has a characteristic convex-upward } \\
\text { profile, dipping } 70^{\circ} \mathrm{S} \text { at its base and } \\
40^{\circ} \mathrm{S} \text { at its visible top. }\end{array}$ \\
\hline F7 & $161 / 70$ & $86 \mathrm{E}$ & $2.3 \mathrm{~m}$, reverse & $\begin{array}{l}\text { It comprises two closely-spaced, } \\
\text { anastomosing surfaces, with dips } \\
\text { greater than } 65^{\circ} \mathrm{S} \text {; a secondary splay } \\
\text { develops in the footwall. }\end{array}$ \\
\hline $\mathrm{F} 8$ & $170 / 60$ & $90 \mathrm{E}$ & $0.3 \mathrm{~m}$, reverse & $\begin{array}{l}\text { It consists of anastomosing branches, } \\
\text { which bound lenticular blocks. }\end{array}$ \\
\hline F9 & $155 / 82$ & $90 \mathrm{E}$ & $0.6 \mathrm{~m}$, reverse & $\begin{array}{l}\text { It consists of two, subparallel south- } \\
\text { dipping fractures. }\end{array}$ \\
\hline F10 & $175 / 85$ & $45 \mathrm{E}$ & $\begin{array}{l}1.2 \mathrm{~m} \text {, right- } \\
\text { lateral oblique }\end{array}$ & $\begin{array}{l}\text { Net slip based on apparent vertical } \\
\text { displacement amounts to } 2 \mathrm{~m} \text {. }\end{array}$ \\
\hline F14 & $010 / 80$ & $90 \mathrm{E}$ & $0.6 \mathrm{~m}$, normal & - \\
\hline F16a & $028 / 45$ & $90 \mathrm{E}$ & $\begin{array}{l}0.35 \mathrm{~m}, \\
\text { normal }\end{array}$ & $\begin{array}{l}\text { Within a set of close-spaced faults, } \\
\text { probably merging downdip. }\end{array}$ \\
\hline $\mathrm{F} 16 \mathrm{~b}$ & $017 / 55$ & $65 \mathrm{~W}$ & $0.8 \mathrm{~m}$, normal & Ditto \\
\hline F16c & $175 / 85$ & $60 \mathrm{~W}$ & $\begin{array}{l}>0.5 \text {, oblique- } \\
\text { normal }\end{array}$ & Ditto \\
\hline F16d & $240 / 70$ & $45 \mathrm{E}$ & $\begin{array}{l}\text { ??, oblique- } \\
\text { normal }\end{array}$ & Antithetic to F16c \\
\hline F17 & $345 / 70$ & $54 \mathrm{E}$ & $\begin{array}{l}0.4 \mathrm{~m} \text {, normal- } \\
\text { oblique }\end{array}$ & $\begin{array}{l}\text { Within CMF, also affecting } \\
\text { CMF/fluvials contact. }\end{array}$ \\
\hline FA1 & $168 / 80$ & $72 \mathrm{E}$ & $\begin{array}{l}0.25 \mathrm{~cm} \\
\text { oblique- } \\
\text { reverse }\end{array}$ & - \\
\hline FA2 & $180 / 65$ & $90 \mathrm{E}$ & $0.8 \mathrm{~m}$, normal & Within CMF \\
\hline
\end{tabular}

*: dip/ dip direction average values $\quad * *$ : apparent vertical displacement

With bedding strike being practically parallel the intermediate stress axis and assuming an average of $15^{\circ}$ local bedding dip, restoration of bedding to horizontal rotates the minor and major axes close to horizontal and vertical, respectively $\left(\sigma 1^{\prime}: 141 / 75, \sigma 2^{\prime}: 262 / 08, \sigma 3^{\prime}: 354 / 12\right)$. This means that the local stress field derived from the analysis of the dataset is consistent with the regional one (Clarke et al., 1998). 

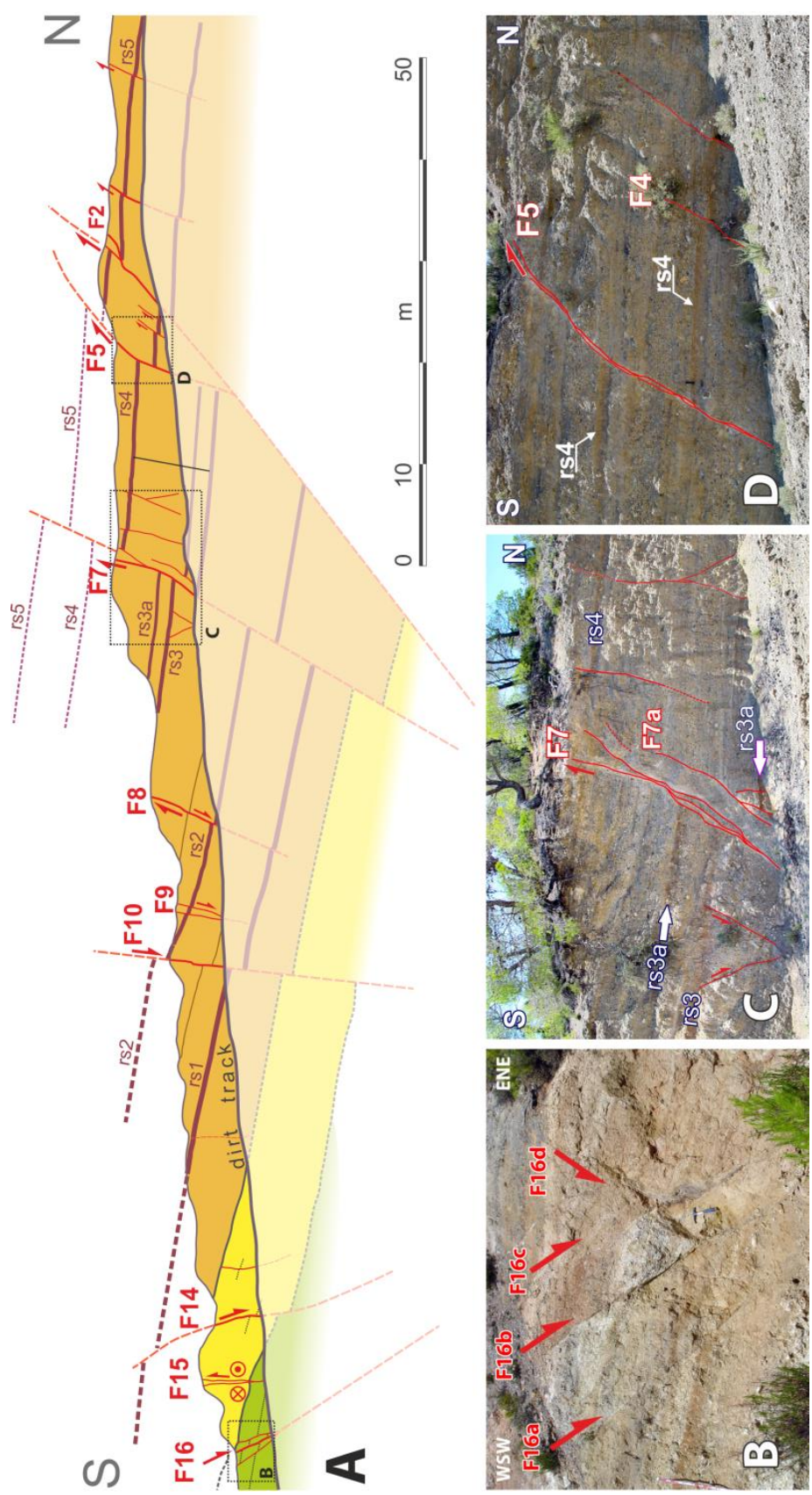

Figure 3 - (A). Log of Section A (above trace of dirt track) and extrapolation of data, below it (shown in washed-out colours). Height of exposed panel ranges from 4-15 m. Extrapolation of faults and strata was made based on mean strike and dip of the features, without assuming any dip changes in faults, down to a depth of ca. $30 \mathrm{~m}$. No vertical exaggeration. The log is practically perpendicular to mean fault strike and at high angle to bedding, so dips shown are very close to true ones. Major palaeosol horizons, on which estimates of apparent vertical throw of the studied faults, are also shown. (B) (B) The fault array of F16. (C) Fault F7, consisting of numerous anastomosing branches Height of section is 5.5 at the centre of the photo. Apparent vertical throw is $2.3 \mathrm{~m}$. (D) Fault F5, with a gently convex-up profile. It consists of two closely-spaced strands, which bound its damage zone. Hammer is $32 \mathrm{~cm}$ long. 

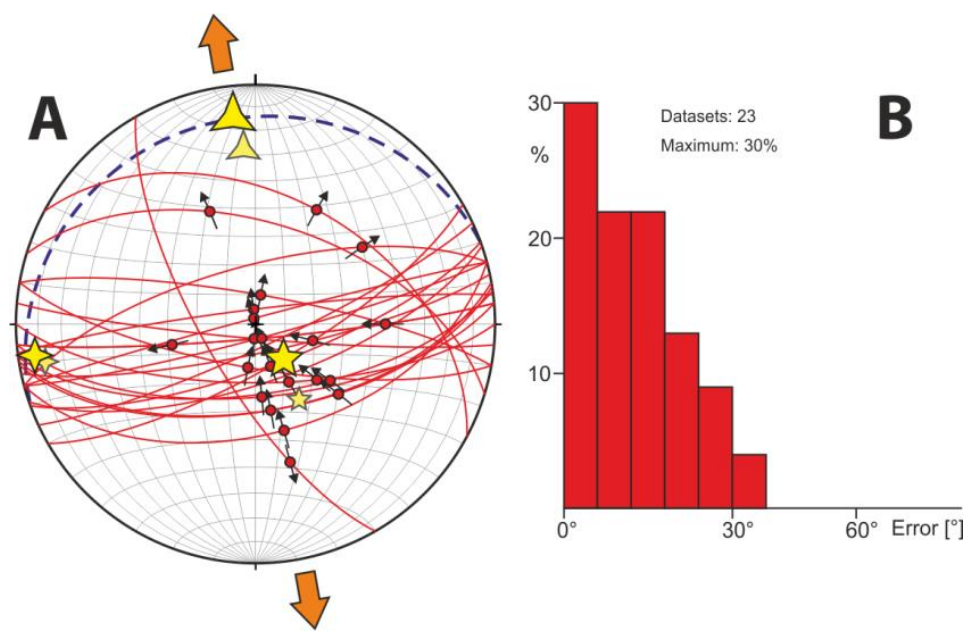

Figure 4 - Stereographic projection (eq. area, l. hemisphere) of faults with good quality kinematic data (solid lines) from Section A and auxiliary location A1. Local bedding is shown in dashed line. Principal stress axes are shown in 5-, 4- and 3-pointed starts for major, intermediate and minor axis, respectively. Restored positions of axes are shown in bold stars, with post-tilting ones in greyed-out symbols (B) Fluctuation histogram.

\subsection{Section $B$}

Section 2 is a mostly inaccessible cliff exposure, located ca $200 \mathrm{~m}$ north of Section A (Fig. 2). The 20-30 m high cliff exposes well-stratified and faulted fluvial deposits, with more or less welldeveloped palaeosol markers, on which estimates on fault kinematics were based (Fig. 8). The exposed fluvial deposits maintain steady northward dips throughout the cliff section, which reveals laterally consistent layers. Except within a damage zone (see below) no tilting or rotation of strata is observed. Identification of marker horizons across a given fault was not straightforward, or always feasible, so we resorted to the identification of palaeosol successions (sets of 3 or more palaeosols) for the estimation of apparent vertical displacements.

Four steep main faults were identified (B1-B4); all strike E-W; B1 and B2 are south-dipping, B3 is practically vertical and B4 is north-dipping. The displacements of Faults B1, B2 and B4 decrease up-section; this is not the case for the most significant structure in this section (B3), which maintains an apparent vertical displacement (north-side up) of ca $4.5 \mathrm{~m}$ throughout the cliff exposure.

Especially Fault B3 appears to consist of two major splays (B3a and B3d, Fig. 8b), which seem to converge dowdip, just under the base of the cliff. B3a dips steeply $\left(>80^{\circ}\right)$ towards the South and displays an apparent displacement of ca $1 \mathrm{~m}$, south-side up, i.e. an apparently reverse fault. B3b comprises numerous anastomosing fractures, with apparently opposing senses of displacement (Fig $8 b$ ). This type of faulting is indicative of a structure which is highly oblique-slip, if not purely strikeslip (Christie-Blick and Biddle, 1985). Coexistence of both apparent normal and reverse separation is also observed in fault B1, albeit with less degree of confidence, with B1a showing an apparent displacement of only a few dm, decreasing to zero close to the top of the section.

The co-occurrence of both apparently reverse and normal faulting, as well as the fact that the most significant fault in this location appears to be highly oblique-slip, together with their spatial arrangement and spacing, suggests that the observed faults may be the upward expression of a strikeslip fault, whose strike is approximately E-W. 


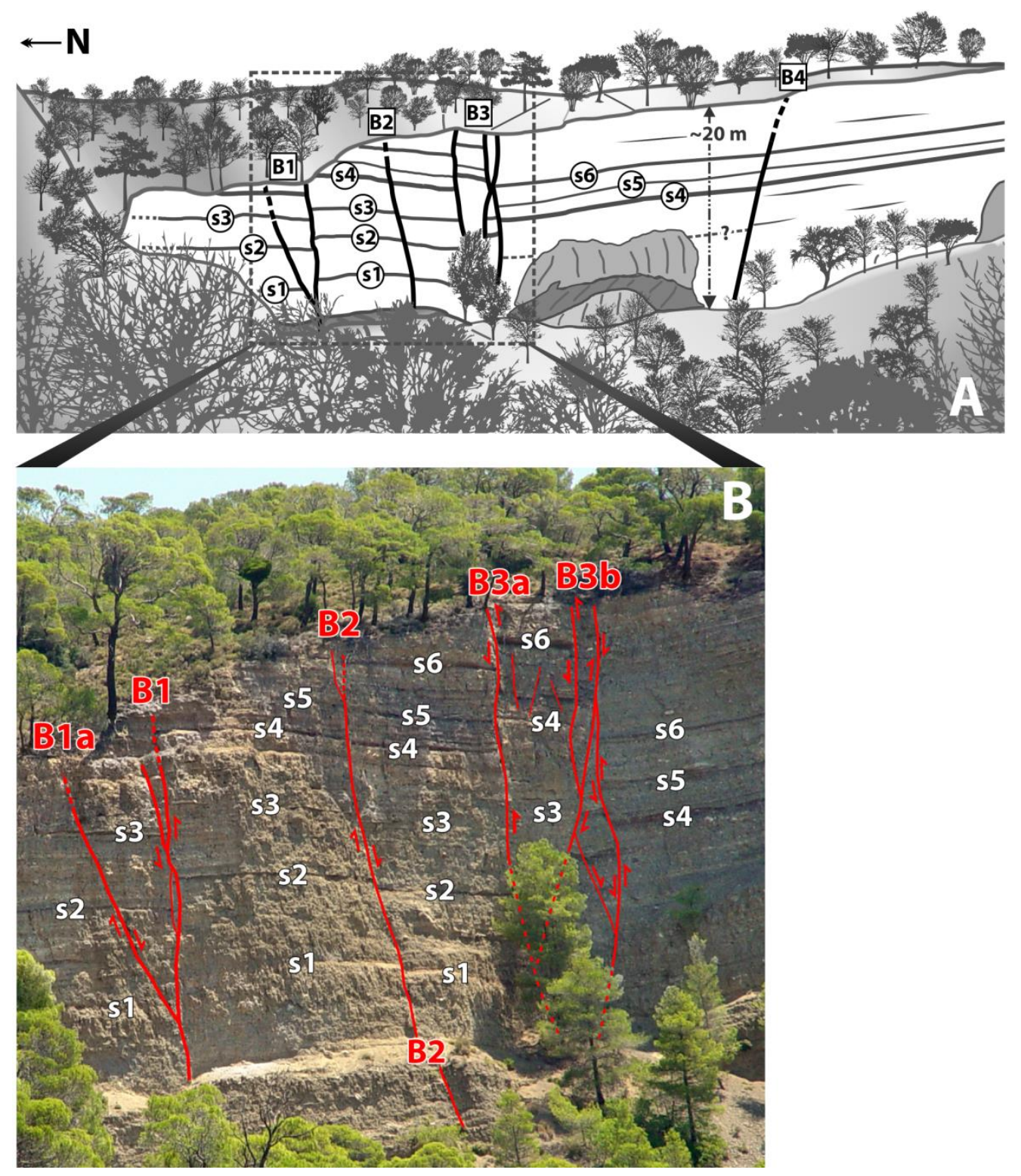

Figure 5 - (A) Sketch panorama of a cliff section through the Pleistocene fluvial deposits.

View to the East. S1-S6 denote laterally persistent palaeosol horizons; B1-B4 are faults.

Sense and magnitude of apparent displacement (omitted for clarity) was determined on the basis of palaeosol successions. (B). Close-up of the inaccessible cliff section, with same palaeosol and fault notation. Height of section is approximately $15 \mathrm{~m}$. Fault B1 shows apparent reverse displacement and splits updip in two splays, which seem to tip off close to the top of the section. Fault B1a, truncated by B1, shows minor apparent normal separation. B2 shows decametric normal separation, dying up-section. Fault B3 consists of two branches (B3a and B3b), which appear to link downdip, while minor fractures between the two splays, at the upper part of the section, are also indicative of linkage between the two. Apparent vertical offset across $B 3$ is ca $4.5 \mathrm{~m}$. Fault B3b presents a 2-3 m wide damage zone, consisting of numerous anastomosing splays, with contrasting sense of displacement, indicative of its being degree of oblique-slip (if not purely strike-slip). 


\section{Discussion - Implications}

The fault sets identified in Sections A and B are probable expressions of strike-slip faulting which has affected both the overlying fluvial deposits and the underlying CMF. Especially, the kinematics, geometry and outcrop pattern of the faults exposed in Section A allow us to consider them as being parts of a flower structure (most probably a positive one), related to an E-W dextral strike-slip fault. East-West strike-slip faulting is also the dominant feature in Section B.

If this is the case, the deformation pattern in the study area is represented by a set of flower structures related to E-W dextral strike-slip faulting. This is compatible with a right-lateral transtensional stress field at an angle of ca $15-20^{\circ}$, exerted at the tips of the overlapping oblique-slip faults, namely the LF in the west and the KSF in the east, both of which strike ENE-WSW.

The mapping of Mack et al. (2009) suggests that the KSF can be extending further west (through is southern segment), to overlap with the eastern part of the LF, with an offset of ca $2 \mathrm{~km}$. The fact that most identified faults are reverse is not incompatible with the overall stress field, as revealed by fault-slip analysis. Indeed, fault slip analysis shows that extensional structures within this accommodation zone should ideally strike NW-SE (and this is the case for the few normal faults identified in Section A), while reverse structures should be ENE-WSW to E-W, as is the case in our study area. The fact that few extensional structures have been found and mapped is attributed to poor field conditions (it is a densely forested area) and the lithological composition of the Pleistocene fluvials.

It is not certain whether KSF and LF are hard-linked or not, as structural mapping and observations are obstructed, for reasons stated above. The fact that only few NE-SW normal faults have been identified can be attributed to the limited outcrops and the orientation of exposures which hinder the identification of structures highly oblique or parallel to them. Another plausible explanation would be that the linkage between the KSF and LF remained at an early stage, where kinematically independent faults develop within the accommodation zone, with their kinematics, however, reflecting the regional stress pattern (e.g. Çiftçi and Bozkurt, 2007). The latter is, in our opinion a more plausible explanation.

The deviation of computed $\sigma 1$ and $\sigma 3$ from vertical and horizontal, respectively, could be related to subsequent block-tilting of the entire area. The fact that $\sigma 2$ remains horizontal facilitates the hypothesis that rotation took place around a horizontal, WSW-ENE axis, parallel to the strike of the major faults in the area. If this is the case, then the area can have been back-tilted, belonging in the footwall of a WSW-ESE fault system further south (basinwards), a member of which is the Kalamaki fault, which has been shown to be active in the Late Quaternary (Pananikolaou et al., 2015). Finally, the fact that the deduced extension direction at Dárthiza is practically identical to the present-day one (Clarke et al., 1998) raises some doubt as to whether the LF is an inactive structure, without any Late Quaternary activity.

\section{References}

Angelier, J. and Goguel, J., 1979. Sur une méthode simple de détermination des axes principaux des contraintes pour une population de failles, Comptes Rendus Hebdomadaires des Séances de l'Academie des Sciences, Serie D, Sciences Naturelles, 288(3), 307-310.

Charalampakis, M., Lykousis, V., Sakellariou, D., Papatheodorou, G. and Ferentinos, G., 2014. The tectono-sedimentary evolution of the Lechaion Gulf, the south eastern branch of the Corinth graben, Greece, Marine Geology, 351, 58-75, doi: 10.1016/j.margeo.2014.03.014.

Christie-Blick, N. and Biddle, K.T., 1985. Deformation and basin formation along strike-slip faults. In: Biddle, K.T. and Christie-Blick, N., eds., Strike-slip deformation, basin formation and sedimentation, SEPM, Sp. Publication, 37, 1-35.

Çiftçi, N.B. and Bozkurt, E., 2007. Anomalous stress field and active breaching at relay ramps: a field example from Gediz Graben, SW Turkey, Geological Magazine 144, 687-699. 
Clarke, P.J., Davies, R.R., England, P.C., Parsons, B., Billiris, H., Paradissis, D., Veis, G., Cross, P.A., Denys, P.H., Ashkenazi, V., Bingley, R., Kahle, H.G., Muller, M.V. and Briole, P., 1998. Crustal strain in central Greece from repeated GPS measurements in the interval 19891997, Geophysical Journal International, 135, 195-214.

Collier, R.E.L. and Dart, C.J., 1991. Neogene to Quaternary rifting, sedimentation and uplift in the Corinth Basin, Greece, J. Geol. Society London, 148, 1049-1065.

Freyberg, B., 1973. Geologie des Isthmus von Korinth, Erlanger Geologische Abhandlugen, 95, 6-160.

Gaitanakis, P., Mettos, A. and Fytikas, M., 1985. Geological Map of Greece, scale 1:50,000, Sofikon Sheet. IGME, Athens.

Kranis, H., Skourtsos, E., Gawthorpe, R., Leeder, M. and Stamatakis, M., 2015. Pre-rift basement structure and syn-rift faulting at the eastern onshore Gulf of Corinth Rift, Geophysical Research Abstracts, 17, EGU2015-2575, EGU General Assembly 2015.

Leeder, M.R., Mack, G.H., Brasier, A.T., Parrish, R.R., McIntosh, W.C., Andrews, J.E. and Duermeijer, C.E., 2008. Late-Pliocene timing of Corinth (Greece) rift-margin fault migration, Earth and Planetary Science Letters, 274, 132-141.

Mack, G.H., Leeder, M.R. and Perez-Arlucea, M., 2009. Late Neogene rift-basin evolution and its relation to normal fault history and climate change along the southwestern margin of the Gerania Range, central Greece, Geological Society of America Bulletin, 121, 907-918.

Nixon, C., McNeill, L., Bull, J., Henstock, T., Bell, R., Gawthorpe, R., Christodoulou, D., Kranis, H., Ferentinos, G., Papatheodorou, G., Taylor, B., Ford, M., Sakellariou, D., Leeder, M., Collier, R., Goodliffe, A. and Sachpazi, M., Rapid spatio-temporal variations in rift structure during development of the Corinth Rift, central Greece, Submitted to Tectonics.

Papanikolaou, I.D., Triantaphyllou, M., Pallikarakis, A. and Migiros, G., 2015. Active faulting at the Corinth Canal based on surface observations, borehole data and paleoenvironmental interpretations. Passive rupture during the 1981 earthquake sequence? Geomorphology, 237, 65-78.

Skourtsos, E. and Kranis, H., 2009. Structure and evolution of the western Corinth Rift, through new field data from the Northern Peloponnesus, Geological Society, London, Special Publications, $321,119-138$.

Spang, J.H., 1972. Numerical method for dynamic analysis of calcite twin lamellae, Geological Society of America Bulletin, 83, 467-471.

Sperner, B. and Zweigel, P., 2010. A plea for more caution in fault-slip analysis, Tectonophysics, $482,29-41$. 